\title{
Antitumor mechanisms of bifidobacteria (Review)
}

\author{
HONGYUN WEI ${ }^{1}$, LINLIN CHEN ${ }^{2}$, GUANGHUI LIAN $^{2}$, JUNWEN YANG ${ }^{2}$, \\ FUJUN $L^{2}$, YIYOU ZOU ${ }^{2}$, FANGGEN LU ${ }^{1}$ and YANI YIN ${ }^{2}$ \\ ${ }^{1}$ Department of Gastroenterology, The Second Xiangya Hospital, Central South University, Changsha, Hunan 410011; \\ ${ }^{2}$ Department of Gastroenterology, Xiangya Hospital, Central South University, Changsha, Hunan 410008, P.R. China
}

Received August 10, 2016; Accepted January 5, 2018

DOI: $10.3892 / \mathrm{ol} .2018 .8692$

\begin{abstract}
Cancer remains one of the most common causes of mortality globally. Chemotherapy, one of the major treatment strategies for cancer, primarily functions by targeting the cancer cells and affecting them physiologically, but also affects normal cells, which is a major concern at present. Therefore, adverse effects of chemotherapy drugs, including myelosuppression and liver and kidney damage, are of concern. Now, microbial products have attracted attention in cancer treatment research. Notably, carcinogenesis is considered to be associated with microbial dysbiosis, particularly the positive antitumor effects of bifidobacteria. Although there remains a substantial amount to be understood about the regulation of bifidobacteria, bifidobacteria remain an attractive and novel source of cancer therapeutics. The present review focuses on introducing the latest information on the antitumor effects of bifidobacteria and to propose future strategies for using bifidobacteria in the development of cancer therapeutics.
\end{abstract}

\section{Contents}

1. Introduction

2. Biotransformation function

3. Competitive characteristics of bifidobacteria in a cancer microenvironment

4. Gene and cytokine modulation: Cementing the function of the intestinal barrier

5. Future treatment prospects using bifidobacteria

6. Conclusion

Correspondence to: Dr Yani Yin, Department of Gastroenterology, Xiangya Hospital, Central South University, 87 Xiangya Road, Changsha, Hunan 410008, P.R. China

E-mail: yyn_4711@163.com

Professor Fanggen Lu, Department of Gastroenterology, The Second Xiangya Hospital, Central South University, 139 Renmin Road, Changsha, Hunan 410011, P.R. China

E-mail: lufanggenyao@163.com

Key words: cancer, bifidobacteria, antitumor

\section{Introduction}

Bifidobacterial species are part of the normal human microflora, and exert probiotic effects in humans (1). Previously, several studies reported that bifidobacteria exhibit certain antitumor effects on the development of cancer (2-4). It may work through the mechanisms of fermentation (5), biotransformation (6) and strengthening the intestinal barrier (7), and may potentially function as a treatment method (Fig. 1). For example, Bifidobacterium breve, Bifidobacterium bifidum and Bifidobacterium longum strains isolated from breastfed infants were associated with the fermentation of caprine milk oligosaccharides (8). Owing to the expression of $\beta$-galactosidases (9), they were able to utilize 3'- and 6'-sialyl-lactose as growth substrates when they were included as the only carbon source (8).

Apart from their fermentation function, bifidobacteria may also serve an important function in bioconversion, as they may convert ginsenoside into a deglycosylated form under controlled conditions (10). Furthermore, they affect the composition of gut microbiota; for example, B. breve UCC2003 exhibited growth properties in a mucin-based medium only in the presence of B. bifidum PRL2010, which was demonstrated to metabolize mucin (11). Additionally, the production of specific molecules secreted by $B$. bifidum prevented adhesion attachment and invasion by food-borne pathogens (12). Lactic acid bacteria, including bifidobacteria, were revealed to exert chemopreventative effects on colon, bladder, liver, breast and gastric cancer types (13). The present review discusses the mechanisms involved in the antitumor effect of bifidobacteria.

\section{Biotransformation function}

Biotransformation is among one of the mechanisms by which bifidobacteria exhibit antitumor effects. Essentially, biotransformation function is fulfilled by the conversion of a compound into a usable energy source via a biological process. High numbers of Bifidobacterium may be involved in enterolactone production, which has antitumor effects (14). Bifidobacterium spp. may ferment polyunsaturated fatty acid (linoleic acid) into pectic oligosaccharides (POS), which may delay the development of leukemia and associated cachexia in mice, and, consequently, POS may increase the amount of Bacteroides spp. (15).

Bifidobacteria may also metabolize certain drugs into therapeutically active compounds against a tumor in vitro (6), 
including lapachol and 5-fluorocytosine. Oliveira Silva et al (16) performed experiments using two probiotic strains from the human gut: Bifidobacterium spp. and Lactobacillus acidophilus. Each of them was incubated with lapachol, an anticancer drug, for $12 \mathrm{~h}$ in an anaerobic atmosphere at $37^{\circ} \mathrm{C}(16)$. The culture broths were extracted twice using ethyl acetate, prior to analysis of the chemical profiles of all crude extracts by an injection of $20 \mu \mathrm{l}$ of all crude extracts (tests and controls) from the culture broths at $1 \mathrm{mg} \cdot \mathrm{ml}^{-1}$ using reversed-phase high-performance liquid chromatography. A total of $10^{6}$ colony-forming units $(\mathrm{CFU}) / \mathrm{ml}$ of bifidobacteria was able to convert lapachol into an active compound against breast cancer cell at $37^{\circ} \mathrm{C}$ in an anaerobic atmosphere (16).

Additionally, they may convert nontoxic prodrugs into therapeutically active compounds based on the expression of certain enzymes, including cytosine deaminase (17). This enzyme has the ability to convert the nontoxic prodrug 5-fluorocytosine into 5-fluorouracil, which may inhibit the proliferation of carcinoma cells (18). An antitumor drug named ginsenoside Rb1 may be metabolized into the bioactive compound K when incubated with Bifidobacterium spp. (19). Furthermore, the gut microbiota was additionally analyzed in people with differing levels of ginsenoside $\mathrm{Rb} 1$ degradation into compound $\mathrm{K}$ (6). A total of 5 samples with fecal activity potently metabolizing ginsenoside Rb1 to compound K (FPG) and 5 samples with fecal activity not metabolizing ginsenoside $\mathrm{Rb} 1$ to compound $\mathrm{K}$ (FNG) were selected from a pool of 100 patients, and the fecal microbiota were analyzed using $16 \mathrm{~S}$ ribosomal RNA gene pyrosequencing. It was revealed that the population levels of Bifidobacterium were substantially increased in the FPG group (6). Additionally, lactic fermentation with Bifidobacterium longum subsp. infantis may enhance the antitumor cell proliferation effect of soymilk against HT-29 and Caco-2 colorectal cancer (CRC) cell lines (5).

Bifidobacterium additionally serves a notable function in drug metabolism in vivo, as the consumption of a mixture of goat probiotics, including bifidobacteria, was associated with a decrease in fecal putrescine (a cancer biomarker) and the reduction of mutagen fecal concentration, including benzo $(\alpha)$ pyrene $[\mathrm{B}(\alpha) \mathrm{P}]$, which is involved in the onset of CRC (20). Bifidobacteria demonstrated a strong anti-mutagenic effect on $\mathrm{B}(\alpha) \mathrm{P}(21)$, indicating its function in the prevention of CRC. In addition, the expression and secretion of signal peptides improved the therapeutic effects of bifidobacteria (22). B. longum subsp. infantis exhibited sustainable antitumor growth activity via downregulating peroxiredoxin-1 through the nuclear factor- $\kappa \mathrm{B}$ signaling pathway in a rodent bladder cancer model (23). A previous study by Xiao et al (24) used $B$. longum subsp. infantis thymidine kinase (TK) to treat tumor-bearing nude mice, and revealed that B. longum subsp. infantis TK resulted in substantially effective antitumor activity and a stronger apoptotic response through intrinsic and extrinsic apoptotic pathways compared with normal saline, B. longum subsp. Infantis or B. longum subsp. Infantis/pGEX-1 $\lambda \mathrm{T}$ treatment. A previous observation noted that the dietary administration of lyophilized cultures of $B$. longum suppressed colon and mammary carcinogenesis in laboratory animal models (25). Furthermore, aberrant crypt foci (ACF) may be recognized as early neoplastic lesions, particularly large ACF (26); and ACF induced by

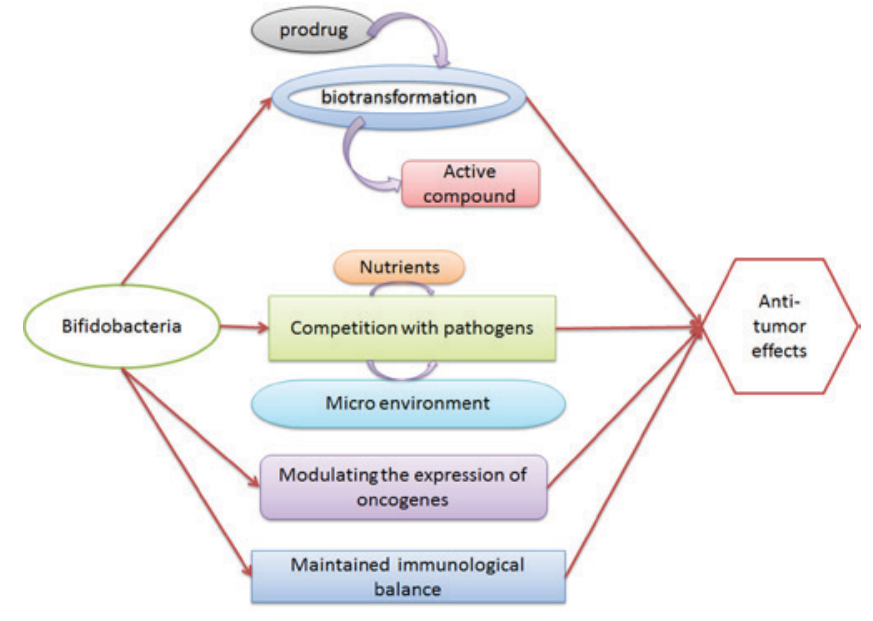

Figure 1. Schematic depiction of the various mechanisms involved in the antitumor effects of bifidobacteria.

azoxymethane were revealed to be decreased in animals fed with B. longum (27). Bifidobacterium animalis subsp. lactis may prevent colon carcinogenesis through inhibiting the formation of large ACF in mice colons (4). Another study revealed that the combined administration of $B$. animalis subsp. lactis and Lactobacillus rhamnosus with inulin in rats was able to decrease the occurrence of azoxymethane-induced malignant tumor types (28). A selenium-enriched B. longum strain may significantly inhibit tumor growth in tumor-bearing mice compared with negative control mice fed with $13 \%$ defatted milk (29). Three cell wall preparations from B. longum subsp. infantis revealed a high activity in tumor suppression and tumor regression tests on mice (30).

\section{Competitive characteristics of bifidobacteria in a cancer microenvironment}

Bifidobacterium has an apparent competitive advantage in the cancer microenvironment. The administration of B. longum resulted in a decrease in fecal $\mathrm{pH}$, enabling the bacteria to outcompete commensal intestinal bacteria (31). The probiotic strain $B$. breve $\mathrm{B} 632$ possessed the ability to inhibit gas-producing coliforms, as observed when lowering of the amount of Enterobacteriaceae after $18 \mathrm{~h}$ of cultivation with $B$. breve B632-supplemented microbiota cultures, which accounted for $64 \%$ of bifidobacteria at the steady state, compared with in control cultures (32). Another study revealed that $B$. breve $\mathrm{B} 632$ and $B$. breve $\mathrm{BR} 03$ are able to inhibit certain gram-negative bacteria in vitro in order to integrate into the intestinal microbiota of children (33). Following feeding with a suspension containing $1 \times 10^{8}$ live cells of $B$. breve $\mathrm{B} 632$ or B. breve BR03 daily for 21 days, a significant increase in total fecal bifidobacterial numbers and a parallel decrease in total coliforms was observed compared with the intestinal microbiota of children at the beginning of that study (33).

Secondly, the competitive exclusion of pathogenic microbiota by probiotics includes the competition for nutrients and adhesion at the intestinal mucosa. It has been reported that probiotics compete for limited nutrients available at the distal colon and grow at the expense of other bacteria (34-36). Non-pathogens may compete with pathogens by altering $\mathrm{pH}$ 
and inducing metabolic changes $(37,38)$. Vaginal lactobacilli may produce biosurfactants that are composed of a mixture of proteins, lipids and carbohydrates that help to displace dense mixed cultures of uropathogenic Escherichia coli and Enterococcus faecalis $(39,40)$. The mechanism involved in anti-mutagenic activities is the ability of bifidobacteria to bind to the mutagens of microbial cells (41).

Thirdly, certain Lactobacillus strains may produce substances that kill or inhibit the growth of pathogens, including bacteriocins. Bacteriocins are molecules that may interfere with the cell wall structure and biosynthesis, forming pores in the target bacterial membrane resulting in permeabilization (42). In addition, lactobacilli may also produce hydrogen peroxide $\left(\mathrm{H}_{2} \mathrm{O}_{2}\right)$, which has the potential to kill pathogens in the vagina via the production of free radicals (43), while they protect themselves from the toxic accumulation of $\mathrm{H}_{2} \mathrm{O}_{2}$ through the production of $\mathrm{Fe}^{3+}$-activated extracellular peroxidase (44).

Finally, bifidobacteria have also been demonstrated to exhibit anti-mutagenic activities against heterocyclic amines, $\mathrm{N}$-nitroso compounds and aflatoxins $(45,46)$.

\section{Gene and cytokine modulation: Cementing the function of the intestinal barrier}

Bifidobacteria also exhibit antitumor effects via altering the expression of cancer-associated genes and cytokines. $B$. longum may suppress azoxymethane-induced colonic tumor types, and this effect was associated with a decrease in colonic mucosal proliferation and ornithine decarboxylase and ras-p21 activity $(25,47,48)$. Animal studies have demonstrated that probiotic preparations consisting of bifidobacteria are able to decrease the activity of procarcinogenic enzymes, including $B$. bifidum, which may decrease the activity of $\beta$-glucosidase (49), and B. longum, which was revealed to lower $\beta$-glucosidase and $\beta$-glucuronidase activity (50). In addition, microbiota-associated inflammatory processes may contribute to carcinogenesis in the affected organs. For example, chronic Helicobacter pylori infection results in gastric cancer, and hepatitis B virus results in hepatic cancer $(51,52)$.

However, the question of how they promote colon tumor formation remains unanswered. Patients with CRC exhibit bacteria adhering to tumor tissue (53) and have indirect evidence of bacterial invasion $(54,55)$. Human gut commensal bifidobacteria strains have the ability to adhere to human epithelial cells (56). Exposure of B. longum subsp. infantis to human milk oligosaccharides resulted in an increased ability to adhere to intestinal cells and increase the expression of the anti-inflammatory cytokine interleukin (IL)-10 (57-59). In an animal model of post-infectious irritable bowel syndrome, which was established by infection with Trichinella spiralis for 8 weeks, B. longum intervention may increase the expression level of NLR family pyrin domain-containing 3 inflammasome and the downstream cytokines IL-8 and IL-1 $\beta$ (60). For immune cells, B. longum BB536 serves an important function in the development and maturation of the immune system. Interferon $\gamma($ IFN- $\gamma$ ) secreting cells and the proportion of IFN- $\gamma / \mathrm{IL}-4$ secreting T helper (Th) cells (Th1/Th2) were increased in newborn infants supplemented with B. longum BB536 (61). Wu et al (62) explored the immunological mechanism of colonic carcinogenesis using enterotoxigenic Bacteroides fragilis (ETBF) and revealed a signal transducer and activator of transcription 3- and Th17-dependent pathway used in inflammation-induced cancer by ETBF. The beneficial effects of probiotics are thought to maintain the balance between types of $\mathrm{T}$ cell responses including $\mathrm{T}$ regulatory (Treg) and Th17 responses. The beneficial effects of probiotics are thought to keep balance between types of $\mathrm{T}$ cell response such as T regulatory (Treg) and Th17 responses $(63,64)$. Th17 cells serve a key function in inducing tissue inflammation in autoimmune disease (65), and Treg cells function as master regulators of the immune response (66). However, B. animalis subsp. lactis was demonstrated to increase forkhead box $\mathrm{P}^{+}$mRNA, which defines the Treg lineage and expression in peribronchial lymph nodes, suggesting the induction of Treg cells by this strain (67). Bifidobacterium-treated mice revealed significantly limited tumor growth in comparison with non-Bifidobacterium-treated counterparts, which was accompanied by the induction of tumor-specific $\mathrm{T}$ cells in the periphery and an increased accumulation of antigen-specific cluster of differentiation $8(\mathrm{CD} 8)^{+} \mathrm{T}$ cells within the tumor (68).

Furthermore, the therapeutic effect of Bifidobacterium feeding was abrogated in CD8-depleted mice, indicating that the therapeutic effect of bifidobacteria on a tumor was dependent on antitumor immunity activity (68). In a study by Yin et al (69), B. longum was transfected by electroporation with pBV22210 containing IL-2 (B. longum-pBV22210-IL-2), and its inhibitory effect on transplanted tumor types in mice was examined. When cyclophosphamide was combined with B. longum-pBV22210-IL-2, the survival times of the mice were longer compared with any of them alone, indicating that B. longum-pBV22210-IL-2 has potent antitumor effects that may be enhanced when combined with chemotherapeutic drugs (69). Subjects using non-steroidal anti-inflammatory drugs compared with non-users had reduced numbers of Collinsella spp. and Roseburia spp., which are associated with the development of CRC (70). This means these bacteria require inflammatory niches to colonize the bowel wall (71). Therefore, an intact mucosa barrier is the key to protection from CRC development. First, Bifidobacterium may stabilize claudins at tight junctions (72). The administration of B. longum subsp. infantis BB-02 $\left(3 \times 10^{6} \mathrm{CFU}\right.$ in $\left.20 \mu \mathrm{l}\right)$ may decrease intestinal permeability in a necrotizing enterocolitis mice model by upregulating the expression of occludin and claudins 2, 4 and 7 (72). This function was also observed in enterocyte-like human colon adenocarcinoma cells and T84 cells (59,73). Secondly, bifidobacteria may affect mucosal metabolism and function, and be involved in colon cancer development via altering the expression of the intestinal differentiation factors, including Hes family basic helix-loop-helix (BHLH) transcription factor 1, atonal BHLH transcription factor 1 and Krüppel-like factor 4, which govern goblet cells (74).

\section{Future treatment prospects using bifidobacteria}

As bifidobacteria are non-pathogenic and anaerobic, and may selectively localize and proliferate in a hypoxic environment in a number of solid tumor types (75), transfected or constructed bifidobacteria as a novel delivery system for 
specific genes is a promising therapeutic method for treating a tumor. For example, vascular angiogenesis is required for the growth and metastasis of a tumor (76). B. longum subsp. infantis transfected with fms-like tyrosine kinase receptor, a receptor for vascular endothelial growth factor, was verified to exert a potential effect on Lewis lung carcinoma in mice (77). Additionally, tumstatin (Tum) is an endogenous angiogenesis inhibitor (78). Wei et al (79) developed a delivery system for Tum using engineered B. longum (BL-Tum), used them to treat tumor-bearing mice, and revealed that the tumor in the BL-Tum group grew slowly with no metastasis observed. In another study, Nakamura et al (18) transfected B. longum with the plasmid Pbles100-S-eCD, which included the gene encoding cytosine deaminase. This transfected B. longum, which produced active cytosine deaminase that converted 5-fluorocytosine into 5-fluorouracil in hypoxic solid tumor types, resulted in 5-fluorouracil concentrations increasing proportionally with the number of the bacilli (with a baseline of $10^{3} \mathrm{CFU} / \mathrm{ml}$ ). A similar study observed similar results in B. longum subsp. infantis (80).

\section{Conclusion}

In the present review, the role of bifidobacteria in the development of cancer was summarized, as transfected Bifidobacterium have been used to treat tumors in animal models (81). In the future, this novel technology may contribute to the discovery of treatment methods with fewer adverse effects for patients with cancer. However, further investigation of the use of bifidobacteria in the prevention and treatment of cancer is warranted.

\section{Acknowledgements}

Not applicable.

\section{Funding}

The present study was supported by the National Natural Science Foundation of China (grant nos. 81300270 and 81470801).

\section{Availability of data and materials}

All data generated or analyzed during this study are included in this published article.

\section{Authors' contributions}

LC and HW collected the data and wrote the manuscript. GL, JY and FLi collected the data. YZ and FLu analyzed the data. YY conceived the idea for the study and revised the manuscript.

\section{Ethics approval and consent to participate}

Not applicable.

\section{Consent for publication}

Not applicable.

\section{Competing interests}

The authors declare that they have no competing interests.

\section{References}

1. Bottacini F, van Sinderen D and Ventura M: Omics of bifidobacteria: Research and insights into their health-promoting activities. Biochem J 474: 4137-4152, 2017.

2. Biarc J, Nguyen IS, Pini A, Gossé F, Richert S, Thiersé D, Van Dorsselaer A, Leize-Wagner E, Raul F, Klein JP and Schöller-Guinard M: Carcinogenic properties of proteins with pro-inflammatory activity from Streptococcus infantarius (formerly S. bovis). Carcinogenesis 25: 1477-1484, 2004.

3. Wei C, Xun AY, Wei XX, Yao J, Wang JY, Shi RY, Yang GH, Li YX, Xu ZL, Lai MG, et al: Bifidobacteria expressing tumstatin protein for antitumor therapy in tumor-bearing mice. Technol Cancer Res Treat 15: 498-508, 2016.

4. Liboredo JC, Anastácio LR, Pelúzio Mdo C, Valente FX, Penido LC, Nicoli JR and Correia MI: Effect of probiotics on the development of dimethylhydrazine-induced preneoplastic lesions in the mice colon. Acta Cir Bras 28: 367-372, 2013.

5. Lai LR, Hsieh SC, Huang HY and Chou CC: Effect of lactic fermentation on the total phenolic, saponin and phytic acid contents as well as anti-colon cancer cell proliferation activity of soymilk. J Biosci Bioeng 115: 552-556, 2013.

6. Kim KA, Jung IH, Park SH, Ahn YT, Huh CS and Kim DH: Comparative analysis of the gut microbiota in people with different levels of ginsenoside Rb1 degradation to compound $\mathrm{K}$. PloS One 8: e62409, 2013.

7. Schroeder BO, Birchenough GMH, Stahlman M, Arike L, Johansson MEV, Hansson GC and Bäckhed F: Bifidobacteria or fiber protects against diet-induced microbiota-mediated colonic mucus deterioration. Cell Host Microbe 23: 27-40.e7, 2018.

8. Thum C, Roy NC, McNabb WC, Otter DE and Cookson AL: In vitro fermentation of caprine milk oligosaccharides by bifidobacteria isolated from breast-fed infants. Gut Microbes 6: 352-363, 2015.

9. Asakuma S, Hatakeyama E, Urashima T, Yoshida E, Katayama T, Yamamoto K, Kumagai H, Ashida H, Hirose J and Kitaoka M: Physiology of consumption of human milk oligosaccharides by infant gut-associated bifidobacteria. J Biol Chem 286 : 34583-34592, 2011.

10. Ku S, You HJ, Park MS and Ji GE: Effects of ascorbic acid on $\alpha$-l-arabinofuranosidase and $\alpha-1$-arabinopyranosidase activities from RD47 and its application to whole cell bioconversion of ginsenoside. J Korean Soc Appl Biol Chem 58: 857-865, 2015.

11. Egan M, Motherway MO, Kilcoyne M, Kane M, Joshi L, Ventura $M$ and van Sinderen D: Cross-feeding by Bifidobacterium breve UCC2003 during co-cultivation with Bifidobacterium bifidum PRL2010 in a mucin-based medium. BMC Microbiol 14: 282, 2014

12. Bayoumi MA and Griffiths MW: In vitro inhibition of expression of virulence genes responsible for colonization and systemic spread of enteric pathogens using Bifidobacterium bifidum secreted molecules. Int J Food Microbiol 156: 255-263, 2012.

13. Kim JE, Kim JY, Lee KW and Lee HJ: Cancer chemopreventive effects of lactic acid bacteria. J Microbiol Biotechnol 17: 1227-1235, 2007.

14. Oikarinen S, Heinonen S, Karppinen S, Mättö J, Adlercreutz H, Poutanen K and Mutanen M: Plasma enterolactone or intestinal Bifidobacterium levels do not explain adenoma formation in multiple intestinal neoplasia (Min) mice fed with two different types of rye-bran fractions. Br J Nutr 90: 119-125, 2003.

15. Bindels LB, Neyrinck AM, Salazar N, Taminiau B, Druart C, Muccioli GG, Francois E, Blecker C, Richel A, Daube G, et al: Non digestible oligosaccharides modulate the gut microbiota to control the development of leukemia and associated cachexia in mice. PloS One 10: e0131009, 2015.

16. Oliveira Silva E, Cruz de Carvalho T, Parshikov IA, Alves dos Santos R, Silva Emery F and Jacometti Cardoso Furtado NA: Cytotoxicity of lapachol metabolites produced by probiotics. Lett Appl Microbiol 59: 108-114, 2014.

17. Hidaka A, Hamaji Y, Sasaki T, Taniguchi S and Fujimori M: Exogenous cytosine deaminase gene expression in Bifidobacterium breve I-53-8w for tumor-targeting enzyme/ prodrug therapy. Biosci Biotechnol Biochem 71: 2921-2926, 2007. 
18. Nakamura T, Sasaki T, Fujimori M, Yazawa K, Kano Y, Amano J and Taniguchi S: Cloned cytosine deaminase gene expression of Bifidobacterium longum and application to enzyme/pro-drug therapy of hypoxic solid tumors. Biosci Biotechnol Biochem 66 2362-2366, 2002.

19. Bae EA, Park SY and Kim DH: Constitutive beta-glucosidases hydrolyzing ginsenoside $\mathrm{Rb} 1$ and $\mathrm{Rb} 2$ from human intestinal bacteria. Biol Pharm Bull 23: 1481-1485, 2000

20. Apás AL, Dupraz J, Ross R, González SN and Arena ME: Probiotic administration effect on fecal mutagenicity and microflora in the goat's gut. J Biosci Bioeng 110: 537-540, 2010.

21. Lo PR, Yu RC, Chou CC and Huang EC: Determinations of the antimutagenic activities of several probiotic bifidobacteria under acidic and bile conditions against benzo[a]pyrene by a modified Ames test. Int J Food Microbiol 93: 249-257, 2004.

22. Osswald A, Westermann C, Sun Z and Riedel CU: A phytasebased reporter system for identification of functional secretion signals in bifidobacteria. PloS One 10: e0128802, 2015.

23. Jiang L, Xiao X, Ren J, Tang Y, Weng H, Yang Q, Wu M and Tang W: Proteomic analysis of bladder cancer indicates Prx-I as a key molecule in BI-TK/GCV treatment system. PloS One 9 : e98764, 2014.

24. Xiao X, Jin R, Li J, Bei Y and Wei T: The antitumor effect of suicide gene therapy using Bifidobacterium infantis-mediated herpes simplex virus thymidine kinase/ganciclovir in a nude mice model of renal cell carcinoma. Urology 84: 982 .e15-e20, 2014.

25. Reddy BS: Possible mechanisms by which pro- and prebiotics influence colon carcinogenesis and tumor growth. J Nutr 129 (7 Suppl): S1478-S1482, 1999.

26. Rodrigues MA, Silva LA, Salvadori DM, De Camargo JL and Montenegro MR: Aberrant crypt foci and colon cancer: Comparison between a short- and medium-term bioassay for colon carcinogenesis using dimethylhydrazine in Wistar rats. Braz J Med Biol Res 35: 351-355, 2002.

27. Kulkarni N and Reddy BS: Inhibitory effect of Bifidobacterium longum cultures on the azoxymethane-induced aberrant crypt foci formation and fecal bacterial beta-glucuronidase. Proc Soc Exp Biol Med 207: 278-283, 1994.

28. Femia AP, Luceri C, Dolara P, Giannini A, Biggeri A, Salvadori M, Clune Y, Collins KJ, Paglierani M and Caderni G: Antitumorigenic activity of the prebiotic inulin enriched with oligofructose in combination with the probiotics Lactobacillus rhamnosus and Bifidobacterium lactis on azoxymethane-induced colon carcinogenesis in rats. Carcinogenesis 23: 1953-1960, 2002

29. Yin Y, Wang RR, Wang Y, Wang JJ and Xu GX: Preparation of selenium-enriched Bifidobacterium longum and its effect on tumor growth and immune function of tumor-bearing mice. Asian Pac J Cancer Prev 15: 3681-3686, 2014.

30. Sekine K, Toida T, Saito M, Kuboyama M, Kawashima T and Hashimoto Y: A new morphologically characterized cell wall preparation (whole peptidoglycan) from Bifidobacterium infantis with a higher efficacy on the regression of an established tumor in mice. Cancer Res 45: 1300-1307, 1985.

31. Rowland IR, Rumney CJ, Coutts JT and Lievense LC: Effect of Bifidobacterium longum and inulin on gut bacterial metabolism and carcinogen-induced aberrant crypt foci in rats. Carcinogenesis 19: $281-285,1998$

32. Simone M, Gozzoli C, Quartieri A, Mazzola G, Di Gioia D, Amaretti A, Raimondi S and Rossi M: The probiotic Bifidobacterium breve B632 inhibited the growth of Enterobacteriaceae within colicky infant microbiota cultures. Biomed Res Int 2014: 301053, 2014.

33. Mogna L, Del Piano M and Mogna G: Capability of the two microorganisms Bifidobacterium breve B632 and Bifidobacterium breve BR03 to colonize the intestinal microbiota of children. J Clin Gastroenterol 48 (Suppl 1): S37-S39, 2014.

34. Fooks LJ and Gibson GR: Probiotics as modulators of the gut flora. Br J Nutr 88 (Suppl 1): S39-S49, 2002.

35. Dhanani AS and Bagchi T: Lactobacillus plantarum CS24.2 prevents $E$. coli adhesion to HT-29 cells and also down-regulates enteropathogen induced TNF- $\alpha$ and IL-8 expression. Microbiol Immunol 57: 309-315, 2013.

36. Tareb R, Bernardeau M, Gueguen M and Vernoux JP: In vitro characterization of aggregation and adhesion properties of viable and heat-killed forms of two probiotic Lactobacillus strains and interaction with foodborne zoonotic bacteria, especially Campylobacter jejuni. J Med Microbiol 62: 637-649, 2013.

37. Kolenbrander PE, Palmer RJ Jr, Periasamy S and Jakubovics NS: Oral multispecies biofilm development and the key role of cell-cell distance. Nat Rev Microbiol 8: 471-480, 2010.
38. Cadieux PA, Burton J, Devillard E and Reid G: Lactobacillus by-products inhibit the growth and virulence of uropathogenic Escherichia coli. J Physiol Pharmacol 60 (Suppl 6): S13-S18, 2009.

39. McMillan A, Dell M, Zellar MP, Cribby S, Martz S, Hong E, Fu J, Abbas A, Dang T, Miller W and Reid G: Disruption of urogenital biofilms by lactobacilli. Colloids Surf B Biointerfaces 86: 58-64, 2011.

40. Velraeds MM, van de Belt-Gritter B, van der Mei HC, Reid G and Busscher HJ: Interference in initial adhesion of uropathogenic bacteria and yeasts to silicone rubber by a Lactobacillus acidophilus biosurfactant. J Med Microbiol 47: 1081-1085, 1998.

41. Apás AL, González SN and Arena ME: Potential of goat probiotic to bind mutagens. Anaerobe 28: 8-12, 2014.

42. Asaduzzaman SM and Sonomoto K: Lantibiotics: Diverse activities and unique modes of action. J Biosci Bioeng 107: 475-487, 2009.

43. Xu HY, Tian WH, Wan CX, Jia LJ, Wang LY, Yuan J, Liu CM, Zeng $\mathrm{M}$ and Wei $\mathrm{H}$ : Antagonistic potential against pathogenic microorganisms and hydrogen peroxide production of indigenous lactobacilli isolated from vagina of Chinese pregnant women. Biomed Environ Sci 21: 365-371, 2008.

44. Martín R and Suárez JE: Biosynthesis and degradation of $\mathrm{H}_{2} \mathrm{O}_{2}$ by vaginal lactobacilli. Appl Environ Microbiol 76: 400-405, 2010.

45. Lankaputhra WE and Shah NP: Antimutagenic properties of probiotic bacteria and of organic acids. Mutat Res 397: 169-182, 1998.

46. Sreekumar O and Hosono A: The antimutagenic properties of a polysaccharide produced by Bifidobacterium longum and its cultured milk against some heterocyclic amines. Can J Microbiol 44: 1029-1036, 1998.

47. Reddy BS: Prevention of colon cancer by pre- and probiotics: Evidence from laboratory studies. Br J Nutr 80: S219-S223, 1998.

48. Singh J, Rivenson A, Tomita M, Shimamura S, Ishibashi N and Reddy BS: Bifidobacterium longum, a lactic acid-producing intestinal bacterium inhibits colon cancer and modulates the intermediate biomarkers of colon carcinogenesis. Carcinogenesis 18: 833-841, 1997.

49. Verma A and Shukla G: Probiotics Lactobacillus rhamnosus GG, Lactobacillus acidophilus suppresses DMH-induced procarcinogenic fecal enzymes and preneoplastic aberrant crypt foci in early colon carcinogenesis in Sprague Dawley rats. Nutr Cancer 65: 84-91, 2013

50. Lee do K, Jang S, Baek EH, Kim MJ, Lee KS, Shin HS, Chung MJ, Kim JE, Lee KO and Ha NJ: Lactic acid bacteria affect serum cholesterol levels, harmful fecal enzyme activity, and fecal water content. Lipids Health Dis 8: 21, 2009.

51. Suerbaum S and Michetti P: Helicobacter pylori infection. N Engl J Med 347: 1175-1186, 2002.

52. El-Serag HB, Rudolph KL: Hepatocellular carcinoma: Epidemiology and molecular carcinogenesis. Gastroenterology 132: 2557-2576, 2007.

53. Swidsinski A, Khilkin M, Kerjaschki D, Schreiber S, Ortner M, Weber J and Lochs H: Association between intraepithelial Escherichia coli and colorectal cancer. Gastroenterology 115: 281-286, 1998

54. Abdulamir AS, Hafidh RR, Mahdi LK, Al-jeboori T and Abubaker F: Investigation into the controversial association of Streptococcus gallolyticus with colorectal cancer and adenoma. BMC Cancer 9: 403, 2009.

55. Gupta A, Madani R and Mukhtar H: Streptococcus bovis endocarditis, a silent sign for colonic tumour. Colorectal Dis 12: 164-171, 2010.

56. Bernet MF, Brassart D, Neeser JR and Servin AL: Adhesion of human bifidobacterial strains to cultured human intestinal epithelial cells and inhibition of enteropathogen-cell interactions. Appl Environ Microbiol 59: 4121-4128, 1993.

57. Kavanaugh DW, O'Callaghan J, Buttó LF, Slattery H, Lane J, Clyne M, Kane M, Joshi L and Hickey RM: Exposure of Bifidobacterium longum subsp. infantis to milk oligosaccharides increases adhesion to epithelial cells and induces a substantial transcriptional response. PloS One 8: e67224, 2013.

58. Wickramasinghe S, Pacheco AR, Lemay DG and Mills DA: Bifidobacteria grown on human milk oligosaccharides downregulate the expression of inflammation-related genes in Caco-2 cells. BMC Microbiol 15: 172, 2015.

59. Chichlowski M, De Lartigue G, German JB, Raybould HE and Mills DA: Bifidobacteria isolated from infants and cultured on human milk oligosaccharides affect intestinal epithelial function. J Pediatr Gastroenterol Nutr 55: 321-327, 2012. 
60. Gu QY, Zhang J and Feng YC: Role of NLRP3 inflammasome in Bifidobacterium longum-regulated visceral hypersensitivity of postinfectious irritable bowel syndrome. Artif Cells Nanomed Biotechnol 44: 1933-1937, 2016.

61. Wu BB, Yang Y, Xu X and Wang WP: Effects of Bifidobacterium supplementation on intestinal microbiota composition and the immune response in healthy infants. World J Pediatr 12: 177-182, 2016.

62. Wu S, Rhee KJ, Albesiano E, Rabizadeh S, Wu X, Yen HR, Huso DL, Brancati FL, Wick E, McAllister F, et al: A human colonic commensal promotes colon tumorigenesis via activation of Thelper type 17 T cell responses. Nat Med 15: 1016-1022, 2009.

63. Mortaz E, Adcock IM, Folkerts G, Barnes PJ, Paul Vos A and Garssen J: Probiotics in the management of lung diseases. Mediators Inflamm 2013: 751068, 2013.

64. Helwig U, Lammers KM, Rizzello F, Brigidi P, Rohleder V, Caramelli E, Gionchetti P, Schrezenmeir J, Foelsch UR, Schreiber S and Campieri M: Lactobacilli, bifidobacteria and E. coli nissle induce pro- and anti-inflammatory cytokines in peripheral blood mononuclear cells. World J Gastroenterol 12: 5978-5986, 2006.

65. Korn T, Bettelli E, Oukka M and Kuchroo VK: IL-17 and Th17 cells. Ann Rev Immunol 27: 485-517, 2009.

66. Lin W, Truong N, Grossman WJ, Haribhai D, Williams CB, Wang J, Martin MG and Chatila TA: Allergic dysregulation and hyperimmunoglobulinemia E in Foxp3 mutant mice. J Allergy Clin Immunol 116: 1106-1115, 2005.

67. Feleszko W, Jaworska J, Rha RD, Steinhausen S, Avagyan A, Jaudszus A, Ahrens B, Groneberg DA, Wahn U and Hamelmann E: Probiotic-induced suppression of allergic sensitization and airway inflammation is associated with an increase of $\mathrm{T}$ regulatory-dependent mechanisms in a murine model of asthma. Clin Exp Allergy 37: 498-505, 2007.

68. Sivan A, Corrales L, Hubert N, Williams JB, Aquino-Michaels K, Earley ZM, Benyamin FW, Lei YM, Jabri B, Alegre ML, et al: Commensal Bifidobacterium promotes antitumor immunity and facilitates anti-PD-L1 efficacy. Science 350: 1084-1089, 2015.

69. Yin Y, Kou L, Wang JJ and Xu GX: Therapeutic efficacy of Bifidobacterium longum-mediated human interleukin-2 with endostatin or TRAIL in transplanted tumors in mice. Exp Ther Med 3: 481-486, 2012.

70. Bordonaro M, Lazarova DL and Sartorelli AC: Butyrate and Wnt signaling: A possible solution to the puzzle of dietary fiber and colon cancer risk? Cell Cycle 7: 1178-1183, 2008.
71. Mäkivuokko H, Tiihonen K, Tynkkynen S, Paulin L and Rautonen N: The effect of age and non-steroidal anti-inflammatory drugs on human intestinal microbiota composition. Br J Nutr 103: 227-234, 2010.

72. Bergmann KR, Liu SX, Tian R, Kushnir A, Turner JR, Li HL, Chou PM, Weber CR and De Plaen IG: Bifidobacteria stabilize claudins at tight junctions and prevent intestinal barrier dysfunction in mouse necrotizing enterocolitis. Am J Pathol 182: 1595-1606, 2013

73. Ewaschuk JB, Diaz H, Meddings L, Diederichs B, Dmytrash A, Backer J, Looijer-van Langen M and Madsen KL: Secreted bioactive factors from Bifidobacterium infantis enhance epithelial cell barrier function. Am J Physiol Gastrointest Liver Physiol 295: G1025-G1034, 2008

74. Becker S, Oelschlaeger TA, Wullaert A, Vlantis K, Pasparakis M, Wehkamp J, Stange EF and Gersemann M: Bacteria regulate intestinal epithelial cell differentiation factors both in vitro and in vivo. PloS One 8: e55620, 2013.

75. de Vrese $M$ and Schrezenmeir J: Probiotics, prebiotics, and synbiotics. Adv Biochem Eng Biotechnol 111: 1-66, 2008

76. RicciutiB,FogliettaJ,Bianconi V,SahebkarA andPirroM:Enzymes involved in tumor-driven angiogenesis: A valuable target for anticancer therapy. Semin Cancer Biol: S1044-579X(17)30043-3, 2017.

77. Zhu H, Li Z, Mao S, Ma B, Zhou S, Deng L, Liu T, Cui D, Zhao Y, He J, et al: Antitumor effect of sFlt-1 gene therapy system mediated by Bifidobacterium infantis on Lewis lung cancer in mice. Cancer Gene Ther 18: 884-896, 2011.

78. Sudhakar A and Boosani CS: Inhibition of tumor angiogenesis by tumstatin: Insights into signaling mechanisms and implications in cancer regression. Pharm Res 25: 2731-2739, 2008.

79. Wei C, Xun AY, Wei XX, Yao J, Wang JY, Shi RY, Yang GH, Li YX, Xu ZL, Lai MG, et al: Bifidobacteria expressing tumstatin protein for antitumor therapy in tumor-bearing mice. Technol Cancer Res Treat 15: 498-508, 2016.

80. Yi C, Huang Y, Guo ZY and Wang SR: Antitumor effect of cytosine deaminase/5-fluorocytosine suicide gene therapy system mediated by Bifidobacterium infantis on melanoma. Acta Pharmacol Sin 26: 629-634, 2005.

81. Sasaki T, Fujimori M, Hamaji Y, Hama Y, Ito K, Amano J and Taniguchi S: Genetically engineered Bifidobacterium longum for tumor-targeting enzyme-prodrug therapy of autochthonous mammary tumors in rats. Cancer Sci 97: 649-657, 2006. 